\title{
Studies of Genetic Differentiation within Breeds of Japanese Indigenous Chickens
}

\author{
Ikuo Okada, Yoshio Yamamoto, Akihisa Shinjo', \\ Shigeru KimURA ${ }^{2}$ and Hidekazu HiRAOKA ${ }^{3}$ \\ Faculty of Applied Biological Science, Hiroshima University, \\ Saijo, Higashi-Hiroshima 724, Japan \\ ${ }^{1}$ College of Agriculture, University of the Ryukyus, \\ Nishihara 903-01, Japan \\ ${ }^{2}$ Ibaraki Prefectural Poultry Experiment Station, \\ Ibaraki 311-31, Japan \\ ${ }^{3}$ Kochi Prefectural Livestock Experiment Station, \\ Sagawa 789-12, Japan
}

\begin{abstract}
Genetic differentiation within breeds was analyzed using 30 populations belonging to six Japanese and one Bangladesh indigenous breeds and to two improved breeds of chickens. Gene frequencies at four blood group $(A, B, D$ and $E$ ) and 7 blood protein ( $A k p, A k p-2, E s-1, A m y-1, A l b, T f$ and Pas) loci were examined. Although some specific patterns of gene frequencies were observed between breeds, no such patterns were found between local populations within each breed. Genetic distances between the populations within breeds were small. Cluster analysis showed that almost all populations within each breed belonged to one cluster. The estimates of genetic differentiation between local populations within indigenous breeds were smaller than those between strains within improved breeds. These results suggest that in most of Japanese indigenous breeds genetic differentiation between local populations is small.
\end{abstract}

(Jpn. Poult. Sci., $26: 207-215,1989$ )

Key words: gene frequency, genetic distance, coefficient of gene differentiation, indigenous breed

\section{Introduction}

During the last decade several studies of phylogenetic relationships among Japanese indigenous breeds of chickens have been reported ${ }^{1-4)}$. Although some breeds were common to all of these studies, the results of the studies were inconsistent. Since these past studies examined relatively small samples of the birds collected from different areas, the inconsistencies may have been caused either by random fluctuation or by genetic differentiation within breeds.

The object of the present study was to compare local populations within Japanese indigenous breeds of chickens in order to get a clearer insight into local differentiation within the breeds. 


\section{Materials and Methods}

Breeds of chickens examined

Six Japanese indigenous breeds, Hinai-dori, Koeyoshi, Tomaru, Satsuma-dori, Chabo and Utai-chahn, were examined. Two of them, Hinai-dori and Satsuma-dori, developed in Akita and Kagoshima Prefectures, respectively, are nondescript native chickens. Another three breeds, Koeyoshi from Akita area, Tomaru from Niigata Prefecture and Utai-chahn from Ryukyu Islands, are breeds bred for long lasting crowing patterns in males. The sixth breed, Chabo, is the Japanese Bantam, believed to be descendants of chickens imported from Indo-China in the 16th or 17th century.

The samples of birds of these breeds, except the Chabo, were classified by the area where they were collected (Table 1). Most of the samples were collected from areas typical for the breed. However, some samples were collected from the outside of such area and were designated as "others". Samples of the Chabo were collected within the same area, and were classified by plumage color varieties.

For comparison, three foreign breeds, Bangladesh Deshi, White Leghorn and Rhode Island Red, were also tested. The detailed description of Bangladesh Deshi was given by OKADA et $a l .{ }^{5)}$. The samples of White Leghorn and Rhode Island Red chickens were classified by strains. All samples of the strains were obtained from the Shirakawa Livestock Breeding Station, Shirakawa, except for the Hiroshima strain of Rhode Island Red which has been kept at the Hiroshima Prefectural Animal Husbandry Experiment Station, Miyoshi.

Number of birds and populations examined are listed in Table 1.

Blood collection, blood typing and electrophoreses

Heparinized blood samples were collected from a wing vein. Four blood group systems, A, B, D and E, were examined by hemagglutination. The number of reagents used for blood typing were four for the A, nine for the B and two each for the D and $\mathrm{E}$ systems. Seven loci controlling blood plasma proteins were examined by starch or agar gel electrophoresis. The list of loci examined is given in Table 2.

Estimation of gene frequencies and genetic distances

Gene frequencies were estimated by the direct counting method for the loci known to have only codominant alleles. For the loci including recessive alleles gene frequencies were estimated by the method presented by NEIMANN-S $\varnothing$ RENSEN $^{11}{ }^{11}$.

Genetic variability within populations was quantified by measuring the average heterozygosity per individual, $\bar{H}$. The heterozygosity was estimated using the following formula ${ }^{12)}$ :

$$
\bar{H}=\overline{2 n\left(1-\sum_{q i}{ }^{2}\right) /(2 n-1)},
$$

where $q_{i}$ is the frequency of the $i$ th allele at a locus, $n$ is the number of birds of the population concerned, and the bar indicates averaging over all the loci examined.

The relative magnitude of genetic differentiation among populations within breeds was estimated by the coefficient of gene differentiation, $G_{S T}{ }^{13)}$. The coefficient is given by

$$
G_{S T}=D_{S T} / H_{T}
$$


Table 1. List of populations examined in each breed

\begin{tabular}{|c|c|c|c|c|}
\hline Breed & Abbreviation & $\begin{array}{l}\text { No. of } \\
\text { populations }\end{array}$ & $\begin{array}{l}\text { No. of } \\
\text { birds }\end{array}$ & Description of populations \\
\hline Hinai-dori & HIN & 4 & 191 & $\begin{array}{l}\text { A : Akita }{ }^{2} \text { (private farms), B: } \\
\text { Akita (Experiment Station), C : } \\
\text { Aomori }^{2}, \text { D : Others }\end{array}$ \\
\hline Koeyoshi & $\mathrm{KOE}$ & 3 & 128 & A : Akita, B: Aomori, C : Others \\
\hline Tomaru & TOM & 3 & 127 & $\begin{array}{l}\text { A : Niigata }{ }^{2} \text { (private farms), B : } \\
\text { Niigata (Experiment Station), } \\
\text { C: Others }\end{array}$ \\
\hline Satsuma-dori & SAT & 2 & 83 & A : Kagoshima², B : Others \\
\hline Chabo & $\mathrm{CHA}$ & 3 & 74 & $\begin{array}{l}\text { A : Katsura }{ }^{4}, \text { B : Goishi }{ }^{4}, \\
\text { C : Ginzasa }\end{array}$ \\
\hline Utai-chahn & UTA & 2 & 128 & $\begin{array}{l}\text { A : Central area of Okinawa }{ }^{2} \text {, } \\
\text { B : Southern area of Okinawa }\end{array}$ \\
\hline Bangladesh Deshi & BAN & 2 & 170 & $\begin{array}{l}\text { A : Dhaka Division }{ }^{2}, \mathrm{~B}: \text { Chitta- } \\
\text { gong Division }\end{array}$ \\
\hline White Leghorn & LEG & 6 & 180 & $\begin{array}{l}\text { A: } 11^{5}, \text { B: } 62, \mathrm{C}: 68, \mathrm{D}: 74, \mathrm{E}: \\
76, \mathrm{~F}: \mathrm{R} 1^{5}\end{array}$ \\
\hline Rhode Island Red & RIR & 5 & 150 & $\begin{array}{l}\text { A: } 06, \underset{B}{B}: \underset{R}{R}, C: 48, D: 47, E: \\
\text { Hiroshima }\end{array}$ \\
\hline
\end{tabular}

${ }^{1}$ At least, more than 20 birds were examined for each population.

${ }^{2}$ Location of sampling.

${ }^{3}$ Others indicate the samples which were collected from the outside of areas typical for the breed.

${ }^{4}$ Name of variety.

${ }^{5}$ Name of strain.

Table 2. List of polymorphic characteristics examined

\begin{tabular}{|c|c|c|c|}
\hline Characteristics & Locus & Method of analysis & References \\
\hline Blood group & $A$ & Hemagglutination & Matsumoto and OKADA $^{6)}$ \\
\hline " & $B$ & " & " \\
\hline " & $D$ & " & " \\
\hline " & $E$ & $"$ & " \\
\hline Alkaline phosphatase & $A k p$ & Starch gel electrophoresis & OKADA et al. ${ }^{2)}$ \\
\hline " & $A k p-2$ & " & " \\
\hline Esterase & $E s-1$ & " & " \\
\hline Amylase & $A m y-1$ & Agar gel electrophoresis & HASHIGUCHI et al. ${ }^{71}$ \\
\hline Albumin & $A l b$ & Starch gel electrophoresis & MCINDOE ${ }^{8)}$ \\
\hline Transferrin & $T f$ & " & STRATIL ${ }^{9)}$ \\
\hline Postalbumin & Pas & $"$ & Kuryl and Gasparska ${ }^{10}$ \\
\hline
\end{tabular}

where $H_{T}$ is the average heterozygosity of the breed, calculated from average gene frequencies of local populations or strains, and $D_{S T}$ is the difference between the $H_{T}$ and $H_{S}$, the mean of average heterozygosity of local populations or strains.

The genetic distance was measured by a jackknife method using the following formula ${ }^{14)}$ :

$$
\overline{D_{r}}=\frac{1}{r} \sum\left[r D_{r}-(r-1) D_{r, i}\right] \text {, }
$$

where $D_{r}$ is the NeI's genetic distance ${ }^{15)}$ and $D_{r, i}$ is the same as $D_{r}$ except that $i$ th locus has been omitted. The NeI's genetic distance was calculated by the method 
modified for small populations ${ }^{12)}$.

The dendrogram was constructed from the genetic distance matrix by the unweighted pair-group method of SNEATH and SoKAL ${ }^{16)}$.

\section{Results}

Out of 11 loci examined, gene frequencies are given in Table 3 for two loci, blood group $A$ and plasma esterase $E s-1$, as examples. The frequencies of blood group alleles, especially at the $A$ and $B$ loci, showed considerable variation among the breeds. There were ten alleles at the $A$ locus and 23 alleles at the $B$. The number of alleles within the individual breeds varied from 3 to 8 at the $A$ locus and from 3 to 12 at the $B$. The variation between local populations within breeds, however, was not as large

Table 3. Gene frequencies at the blood group $A$ and plasma esterase $E s^{-1}$ loci in each population

\begin{tabular}{|c|c|c|c|c|c|c|c|c|c|c|c|}
\hline \multirow{2}{*}{$\begin{array}{l}\text { Popu- } \\
\text { lation } 1\end{array}$} & \multirow{2}{*}{$\begin{array}{l}\text { No. of } \\
\text { birds }\end{array}$} & \multicolumn{6}{|c|}{$A$} & \multicolumn{4}{|c|}{$E s-1$} \\
\hline & & $F$ & $R$ & $Z$ & $C^{\prime}$ & $a$ & Others & $A$ & $B$ & $C$ & $D$ \\
\hline $\mathrm{HIN}$ - A & 63 & 0 & 0.960 & 0.040 & 0 & 0 & 0 & 0 & 1 & 0 & 0 \\
\hline $\mathrm{HIN}-\mathrm{B}$ & 62 & 0 & 0.815 & 0.186 & 0 & 0 & 0 & 0.444 & 0.556 & 0 & 0 \\
\hline $\mathrm{HIN}-\mathrm{C}$ & 37 & 0 & 0.762 & 0.014 & 0 & 0.224 & 0 & 0.149 & 0.851 & 0 & 0 \\
\hline $\mathrm{HIN}$ - D & 29 & 0 & 0.707 & 0.190 & 0.103 & 0 & 0 & 0.259 & 0.724 & 0.017 & 0 \\
\hline $\mathrm{KOE}-\mathrm{A}$ & 42 & 0.071 & 0.556 & 0 & 0 & 0 & 0.372 & 0.238 & 0.762 & 0 & 0 \\
\hline KOE-B & 57 & 0 & 0.635 & 0 & 0 & 0 & 0.365 & 0.579 & 0.421 & 0 & 0 \\
\hline $\mathrm{KOE}-\mathrm{C}$ & 29 & 0.035 & 0.218 & 0.367 & 0.035 & 0 & 0.346 & 0.190 & 0.810 & 0 & 0 \\
\hline TOM-A & 61 & 0 & 0.758 & 0.016 & 0.033 & 0.193 & 0 & 0.131 & 0.656 & 0.213 & 0 \\
\hline TOM-B & 43 & 0 & 0.784 & 0 & 0 & 0.216 & 0 & 0.233 & 0.767 & 0 & 0 \\
\hline TOM-C & 23 & 0.044 & 0 & 0.398 & 0 & 0.343 & 0.215 & 0.565 & 0.413 & 0.022 & 0 \\
\hline $\mathrm{SAT}-\mathrm{A}$ & 45 & 0 & 0.067 & 0.392 & 0.097 & 0.340 & 0.105 & 0.689 & 0.311 & 0 & 0 \\
\hline SAT-B & 38 & 0.025 & 0.197 & 0.448 & 0.039 & 0.177 & 0.112 & 0.487 & 0.500 & 0.013 & 0 \\
\hline $\mathrm{CHA}-\mathrm{A}$ & 30 & 0.166 & 0 & 0.253 & 0.071 & 0.510 & 0 & 0.345 & 0.293 & 0.362 & 0 \\
\hline CHA-B & 23 & 0.109 & 0 & 0.428 & 0.185 & 0.039 & 0.239 & 0 & 0.870 & 0.130 & 0 \\
\hline $\mathrm{CHA}-\mathrm{C}$ & 21 & 0.106 & 0 & 0.136 & 0.337 & 0.422 & 0 & 0.476 & 0.524 & 0 & 0 \\
\hline UTA-A & 46 & 0.420 & 0 & 0.185 & 0.079 & 0.247 & 0.069 & 0.087 & 0.891 & 0.022 & 0 \\
\hline UTA-B & 82 & 0.246 & 0.043 & 0.211 & 0.090 & 0.266 & 0.144 & 0.171 & 0.829 & 0 & 0 \\
\hline $\mathrm{BAN}-\mathrm{A}$ & 83 & 0.421 & 0.073 & 0.189 & 0.106 & 0.165 & 0.046 & 0.247 & 0.753 & 0 & 0 \\
\hline $\mathrm{BAN}-\mathrm{B}$ & 87 & 0.418 & 0.088 & 0.130 & 0.130 & 0.212 & 0.023 & 0.207 & 0.776 & 0.012 & 0.006 \\
\hline LEG-A & 30 & 0 & 0 & 0.182 & 0.034 & 0.784 & 0 & 0.633 & 0.367 & 0 & 0 \\
\hline LEG-B & 30 & 0 & 0 & 0 & 0.051 & 0.949 & 0 & 1 & 0 & 0 & 0 \\
\hline LEG-C & 30 & 0 & 0 & 0 & 0 & 1 & 0 & 0.783 & 0.217 & 0 & 0 \\
\hline LEG-D & 30 & 0 & 0 & 0.017 & 0.245 & 0.738 & 0 & 0.867 & 0.133 & 0 & 0 \\
\hline LEG-E & 30 & 0 & 0 & 0 & 0.270 & 0.730 & 0 & 0.967 & 0.033 & 0 & 0 \\
\hline LEG-F & 30 & 0 & 0 & 0 & 0.204 & 0.796 & 0 & 0.183 & 0.817 & 0 & 0 \\
\hline $\mathrm{RIR}-\mathrm{A}$ & 30 & 0.151 & 0.203 & 0.147 & 0.045 & 0.069 & 0.385 & 0.183 & 0.817 & 0 & 0 \\
\hline RIR - B & 30 & 0.035 & 0.484 & 0 & 0.092 & 0.389 & 0 & 0.050 & 0.950 & 0 & 0 \\
\hline $\mathrm{RIR}-\mathrm{C}$ & 30 & 0 & 0.166 & 0.184 & 0.034 & 0.616 & 0 & 0.017 & 0.983 & 0 & 0 \\
\hline RIR - D & 30 & 0.102 & 0.039 & 0 & 0.250 & 0.422 & 0.188 & 0.067 & 0.933 & 0 & 0 \\
\hline RIR -E & 30 & 0.017 & 0.678 & 0 & 0 & 0.039 & 0.267 & 0.367 & 0.633 & 0 & 0 \\
\hline
\end{tabular}

${ }^{1}$ See Table 1 for the population symbols. 
Table 4. Mean genetic distances within breeds (on the diagonal) and between breeds (off diagonal)

\begin{tabular}{llllllllll}
\hline \hline Breed $^{1}$ & HIN & KOE & TOM & SAT & CHA & UTA & BAN & LEG & RIR \\
\hline HIN & .0849 & .1564 & .1459 & $.2373^{*}$ & .2276 & .2105 & .1930 & $.3766^{*}$ & $.2144^{*}$ \\
KOE & & .1014 & .1170 & .1553 & .1964 & .1650 & .1402 & .2471 & .1747 \\
TOM & & & .0937 & .1867 & .2209 & $.1875^{*}$ & $.1210^{*}$ & .1851 & .1679 \\
SAT & & & & .0597 & .1377 & .1312 & .1810 & .3086 & .1998 \\
CHA & & & & & .1289 & .1416 & .1890 & $.3781^{*}$ & $.2133^{*}$ \\
UTA & & & & & & .0131 & $.1361^{*}$ & .3419 & .1382 \\
BAN & & & & & & .0069 & $.2202^{*}$ & .1794 \\
LEG & & & & & & & & .0867 & .2573 \\
RIR & & & & & & & & .1414 \\
\hline
\end{tabular}

* Significant at $5 \%$ level, compared with mean distances within relevant breeds.

${ }^{1}$ See Table 1 for the breed abbreviation.

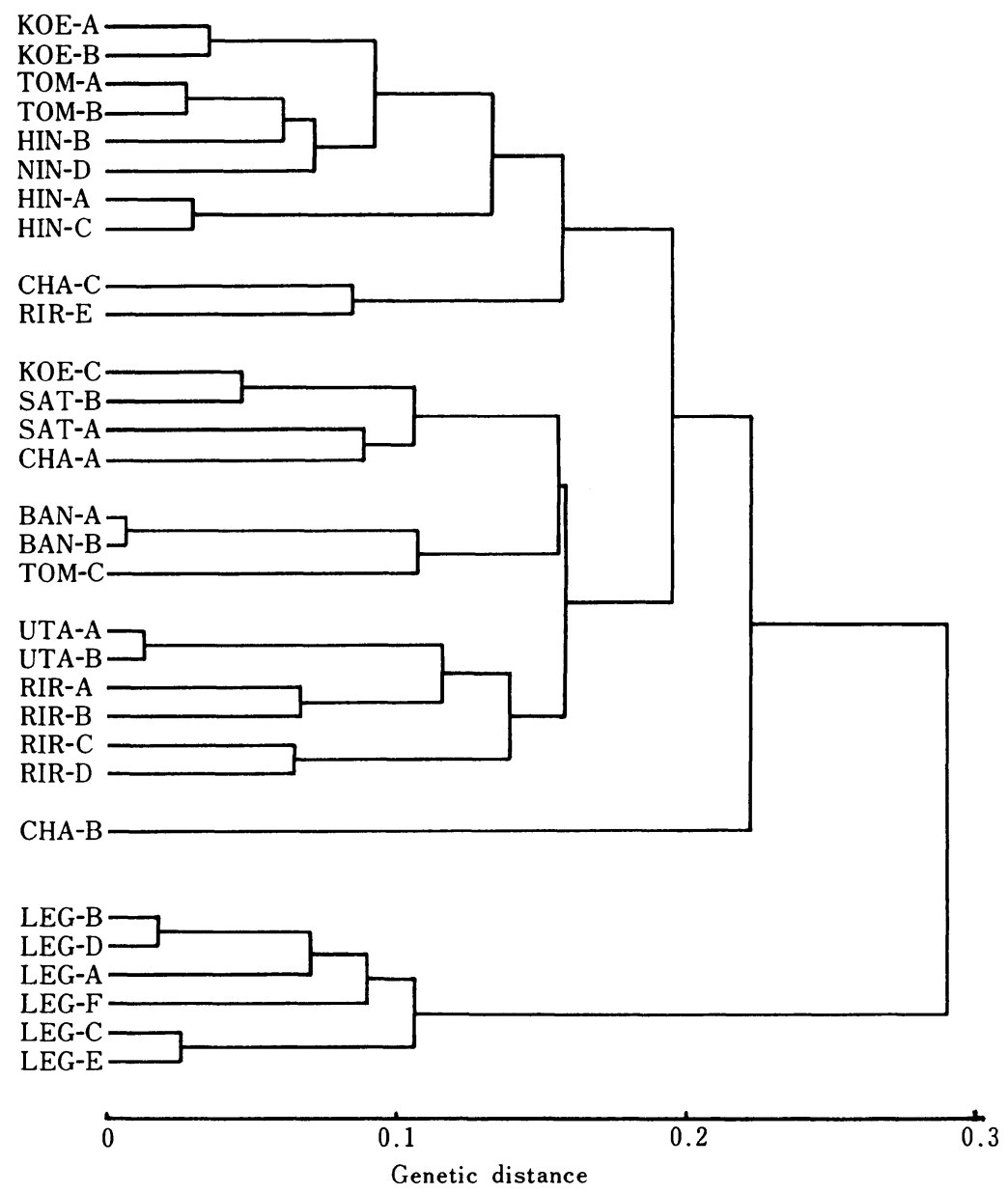

Fig. 1. Dendrogram showing genetic relationships among 30 populations belonging to seven indigenous and two improved breeds. For the population symbols, see Table 1. 
as that among breeds. Furthermore, some features typical for specific breeds were observed. For example, the $A^{F}$ allele was found with high frequencies in all populations of Chabo, Utai-chahn and Bangladesh Deshi, but not in the populations of Hinai-dori and White Leghorn (Table 3). Similar phenomena were also observed at the $B$ locus.

As for blood protein loci, typical features for specific breeds were somewhat less pronounced than those observed at the blood group loci, except for the esterase alleles. At the Es-1 locus, the breeds could be divided into three groups : high frequency of $E s-1^{A}$ (White Leghorn), medium frequency (indigenous breeds) and low frequency (Rhode Island Red) (Table 3).

Genetic distances between every pair of the 30 populations studied were calculated and averaged for every pair of breeds (Table 4). As expected, mean genetic distances between populations from different breeds were considerably larger than those within breeds. Especially, the distances between the populations of White Leghorn and the other breeds were large.

The dendrogram drawn from the genetic distances among the 30 populations is given in Fig. 1 and that drawn from the mean distances within and between breeds in Fig. 2. The cluster analysis assigned populations within a breed generally to the same cluster, except for the Chabo populations that were not classified by the sampled area but by plumage color varieties.

To evaluate genetic differentiation among local populations within breeds, the coefficients of gene differentiation $\left(G_{S T}\right)$ were estimated as shown in Table 5. The

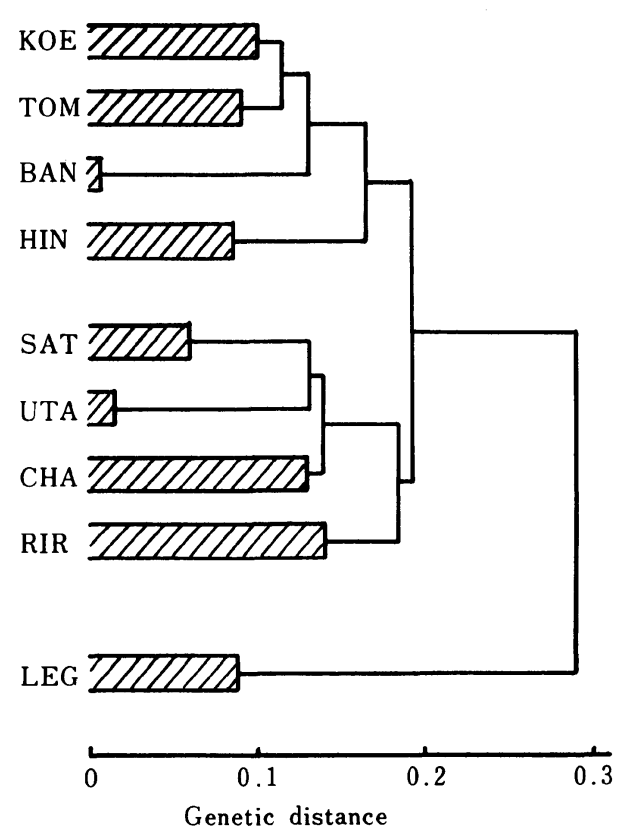

Fig. 2. Dendrogram drawn from the mean genetic distances among 30 populations within and between breeds. Shaded parts show mean distances within each breed. For the breed abbreviations, see Table 1. 
Table 5. Gene differentiation among populations within each breed

\begin{tabular}{lccccc}
\hline \hline Breed $^{1}$ & $\begin{array}{l}\text { No. of } \\
\text { populations }\end{array}$ & $\begin{array}{l}\text { No. of } \\
\text { loci }\end{array}$ & $H_{T}{ }^{2}$ & $H_{S}$ & $G_{S T}$ \\
\hline HIN & 4 & 11 & .3552 & .3283 & .0755 \\
KOE & 3 & 11 & .3714 & .3290 & .1141 \\
TOM & 3 & 11 & .3469 & .3195 & .0791 \\
SAT & 2 & 11 & .4284 & .4091 & .0451 \\
CHA & 3 & 11 & .4151 & .3570 & .1401 \\
UTA & 2 & 11 & .4455 & .4382 & .0163 \\
BAN & 2 & 11 & .4638 & .4620 & .0039 \\
LEG & 6 & 11 & .2459 & .1878 & .2363 \\
RIR & 5 & 11 & .3699 & .2931 & .2077 \\
\hline
\end{tabular}

${ }^{1}$ See Table 1 for the breed abbreviation.

${ }^{2} H_{T}=$ the average heterozygosity of the breed; $H_{S}=$ the mean of average heterozygosity of populations within a breed; $G_{S T}=$ the coefficient of gene differentiation. For details, see text.

esimates of $G_{S T}$ of the indigenous breeds were similar in magnitude to the mean genetic distances within breeds (Table 4), while those of improved breeds, namely White Leghorn and Rhode Island Red, were higher than their mean distances.

\section{Discussion}

Genetic differentiation between local populations or strains within breeds was found in several farm animal species ${ }^{17 \sim 20)}$. In chickens, similar differentiation was observed empirically in some indigenous breeds such as Shamos, distributed widely throughout Japan ${ }^{21)}$. However, to the authors' knowledge, there has been no scientific survey of genetic differentiation of local populations within Japanese indigenous breeds of chickens.

As was shown by cluster analysis in the present study, local populations within each breed formed generally a group in the same cluster (Fig. 1). Thus, the genetic differentiation within breeds was not pronounced. One exception was the Chabo breed. The genetic distances observed among the populations within the Chabos were comparable with those among breeds. In Chabos, the populations sampled in this study were plumage varieties rather than local populations as in the remaining indigenous breeds. It is known that Chabos are usaully mated within plumage varieties, and such mating may have caused the genetic differentiation observed. In the other indigenous breeds, Koeyoshi-C and Tomaru-C deviated from the other populations of the respective breed. Both were comparatively small populations kept in locations distant from the area where the original breed was developed. Such deviation might be caused by random genetic drift.

The $G_{S T}$ values of the Japanese indigenous breeds were generally less than half of those of improved breeds (Table 5). Low estimates of $G_{S T}$ for local populations were also reported in cattle ${ }^{22)}$ and cats $^{23)}$. The present results suggest that local genetic differentiation within breeds did not yet occur to any significant degree in most of Japanese indigenous chickens. The degree of such differentiation was considerably 
smaller than that between strains within the improved breeds of White Leghorns or Rhode Island Reds tested.

\section{Acknowledgements}

The authors are indebted to officers of Shirakawa Livestock Breeding Station, Shirakawa, for their kind help in the collection of blood samples used in this experiment. The authors also thank Dr. J.S. GavorA of Animal Research Centre, Agriculture Canada, for reading the paper in manuscript and offering his valuable suggestions. This study was supported by a Grant-in-Aids for Co-operative Research (No. 60304037) from the Ministry of Education, Science and Culture of Japan.

\section{References}

1) Tanabe, Y. and M. Mizutani (1980) Studies on the phylogenetic relationships of the Japanese native fowl breeds. 3. Genetic distances among the 16 breeds based on 16 loci, and their dendrogram. Jpn. Poult. Sci., $17: 116-121$.

2) Okada, I., K. Toyokawa and I. Takayasu (1980) Genetic relationships of some native chicken breeds in the northern Tohoku district of Japan (Japanese with English summary). Jpn. Poult. Sci., 17: 337-343.

3) Hashiguchi, T., M. Tsuneyoshi, T. Nishida, H. Higashiuwatoko and E. Hiraoka (1981) Phylogenetic relationships determined by the blood protein types of fowls. Jpn. J. Zootech. Sci., 52: 713-729.

4) Okada, I., Y. Yamamoto, T. Hashiguchi and S. Ito (1984) Phylogenetic studies on the Japanese native breeds of chickens. Jpn. Poult. Sci., 21 : 318-329.

5) Okada, I., Y. Maeda, T. Hashiguchi, M.A. Hasnath, M.O. Faruque and M.A. MAJID (1988) Gene constitution of indigenous chickens in Bangladesh. Jpn. Poult. Sci., $25: 15-26$.

6) Matsumoto, K. and I. Okada (1961) The blood group systems in the chicken. Jpn. J. Genet., 36 : 257-267.

7) Hashiguchi, T., M. Yanagida, Y. Maeda and M. Taketomi (1970) Genetical studies on serum amylase isozyme in fowls. Jpn. J. Genet., $45: 341-349$.

8) McIndoe, W.M. (1962) Occurrence of two plasma albumins in the domestic fowl. Nature, $195: 353-354$.

9) Stratil, A. (1968) Transferrin and albumin loci in chickens, Gallus gallus L. Comp. Biochem. Physiol., 24 : 113-121.

10) Kuryl, J. and J. Gasparska (1976) Observations on blood post-albumins and hatchability of chickens. Anim. Blood Grps. Biochem. Genet., $7:$ 241-246.

11) Neimann-Sørensen, A. (1959) Blood group and breed structure as exemplified by three Danish breeds. Acta Agric. Scand., 6 : 115-137.

12) NEI, M. (1978) Estimation of average heterozygosity and genetic distance from a small number of individuals. Genetics, 89 : 583-590.

13) NeI, M. (1973) Analysis of gene diversity in subdivided populations. Proc. Nat. Acad. Sci. USA, 70 : 3321-3323.

14) Mueller, M.D. and F.J. Ayala (1982) Estimation and interpretation of genetic distance in empirical studies. Genet. Res., 40:127-137.

15) Nei, M. (1975) Molecular Population Genetics and Evolution. North-Holland Publ., Amsterdam.

16) Sneath, P.H.A. and R.R. Sokal (1973) Numerical Taxonomy. Freeman, San Francisco.

17) SANDBERG, K. (1967) Milk protein polymorphism in Swedish cattle with special reference to strain differences within the Swedish Friesian breed. Acta Agric. Scand., $17: 127-130$. 
18) Nozawa, K. (1970) Population genetics of farm animals. II. Statistical analyses on the polymorphic populations of goats in south-western islands of Japan. Jpn. J. Genet., $45:$ 45-57.

19) SASAKI, Y. (1988) Studies on genetic differentiation of Japanese Black cattle using polyvariate analysis (In Japanese). In : Studies on Conservation and Evaluation of Japanese Native Livestock, 29-40.

20) Oishi, T., Tsuneo Abe, Takeo Abe, S. Ito, K. Murata, M. Jimbu, A. Nishida, H. Nishoji, I. Sato, M. Kosaka, H. Mikami, K. Kai and M. Kuroki (1985) Selection experiment with swine in different regional environments. VI. Changes in polymorphic gene frequencies during the course of selection. Jpn. J. Swine Sci., 22 : 148-153.

21) Teramoto, I. (1979) Oshamo (In Japanese). In : Jpanese Native Chickens, ed. by S. Koyama. Pet-Life Co., Tokyo, 91-92.

22) Namikawa, T., Y. Tsubota, T. Amano, T. Nishida and H.W. Cyril (1986) Blood protein polymorphisms, blood groups and body-measurements in the loal populations of Sri Lanka native cattle. Rep. Soc. Res. Native Livest., 11 : 95-107.

23) Nozawa, K., M. Fukui and T. Furukawa (1985) Blood-protein polymorphism in the Japanese cats. Jpn. J. Genet., $60: 425-439$.

\title{
日本鶏の品種内分化に関する研究
}

\author{
岡田育穂・山本義雄・新城明久 ${ }^{1}$ ・ \\ 木村 茂 $^{2} \cdot$ 平岡英一 ${ }^{3}$ \\ 広島大学生物生産学部, 東広島市 724 \\ 1琉球大学農学部, 西原町 903-01 \\ 2茨城県養鶏試験場, 茨城町 311-31 \\ 高知県畜産試験場, 佐川町 789-12
}

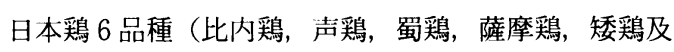
びゥタイチャーン), バングラデシュ在来種 1 品種及び 改良種 2 品種（白色レグホン及びロードアイランドレッ ド）に属する 30 集団を用いて, 鷄の品種内における遺 伝的分化を分析した。調査した遺伝形質は血液型 4 座位 $(A, B, D$ 及び $E)$ 並びに血液蛋白型 7 座位 $(A k p$, $A k p-2, E s-1, A m y-1, A l b, T f$ 及び Pas) の計 11 座位である。これらの座位における遺伀子頻度には品種 差か観察されたが, 各品種内の地域集団間にはあまり差
はみられなかった。品種内の各集団間の遺伝距離は小 さく，デンドログラムではそれぞれの品種内の各集団は ほぼ同一のクラスターに属していた。日本鶏各品種の地 域集団間の遺伝的分化の程度は，改良種における系統差 より小さいと推定された。このように，日本鶏では有意 な品種内分化はまだ生じていないと推测される。

（家禽会誌，26:207〜215，1989） キーワード：遺伝子頻度, 遺伝距離, 遺伝的分化係数, 在来種 